Non-recurrent laryngeal nerve $の 一$ 症例

$\begin{array}{rrrr}\text { 田中 } & \text { 治 } \cdot \text { 山中 } & \text { 敏彰・上田 } & \text { 隆志 } \\ \text { 鶴田 } & \text { 至宏・宮原 } & \text { 裕・松永 } & \text { 喬 }\end{array}$

\title{
A Case Report of Non-Recurrent Laryngeal Nerve
}

\author{
Osamu Tanaka, Toshiaki Yamanaka,Takashi Ueda, Yoshihiro Tsuruta, \\ Hiroshi Miyahara and Takashi Matsunaga \\ (Nara Medical University)
}

\begin{abstract}
During thyroidectomy on a 69-year-old woman with thyroid tumor, the right nonrecurrent laryngeal nerve was encountered. It was rare and on the right side exclusively. Due to its abnormal course and position, the risk of injury to this nerve is high during thyroid surgery.

Thyroidectomy was performed using a standard collar incision with retraction of the strap muscles. The right recurrent laryngeal nerve was not present in the right tracheoesophageal groove. On further dissection, a right non-recurrent laryngeal nerve was found emerging from under the carotid sheath and taking a transverse source to enter the larynx. The nerve was completely preserved. On pathological examination the tumor was a follicular adenoma.
\end{abstract}

Laryngoscopic examination after thyroidectomy showed both vocal cords to be mobile.

Key words: laryngeal nerve, non-recurrent, thyroidectomy

はじめに

反回神経麻痺の主症状は嗄声であり, 程度が ひどいと失声となる。しかも空気濫費量が大き く，会話もとぎれとぎれになり，患者は社会生 活に支障を来すこともある. 反回神経麻㿁の原 因には様々なものがあるが，手術に関するもの では甲状腺手術によるものが最も多い，そのた め甲状腺手術に際しては, 甲状腺と反回神経の 局所解剖を熟知しておくことが必要である。

通常反回神経は, 頸部では食道の前面で気管 の後外側, つまり気管食道溝を上行し, 下喉頭 神経として喉頭にはいる。 しかし稀に反回神経 の走行に破格があり, この点も甲状腺手術を行
ら際に留意すべきと考えられる。今回我々は， 稀な non-recurrent laryngeal nerve の一例を経 験したので，症例を提示するとともに，その成 因・発生頻度などについて文献的考察を行った。

\section{症例}

患 者: 69歳, 女性.

初診日：昭和63年 4 月22日.

主 訴: 嗄声.

既往歴：特記すべきことなし.

家族歴：特記すべきことなし.

現病歴: 初診の10日前より嗄声があり, 精查 を目的として当科を受診した. その際, 右仮声 帯に大きな広基性の垶胞を認め, ラリンゴマイ 
クロサージェリーを行い囊胞を切除した。その 後経過観察中, 術後約 1 个月目に患者の自覚症 状はなかったが，頸部触診にて甲状腺右葉に腫 瘤が指摘され, 手術のため入院した.

局所所見：甲状腺右葉に約 $15 \times 17 \mathrm{~mm}$ 大の 表面平滑, 弾性軟で可動性のある腫瘤を触知し た（図 1 ）。右仮声帯は平坦で術後経過は良く, 両声帯運動も良好であった。

検查所見: 頸部軟 $\mathrm{X}$ 線検査, 甲状腺シンチグ ラムは腫瘍を疑ら所見はなかった。超音波検査 では，甲状腺右葉の腫瘤に一致して約 $20 \mathrm{~mm}$ 大の, 内部ェュー核添均一な腫瘤を認めた。穿 刺吸引細胞診では class IIであった．以上の所 見から本症例を甲状腺良性腫瘍と診断したが， 本人の希望もありただちに手術を行った。

手術所見：1988年10月 4 日，全身麻酔下に甲

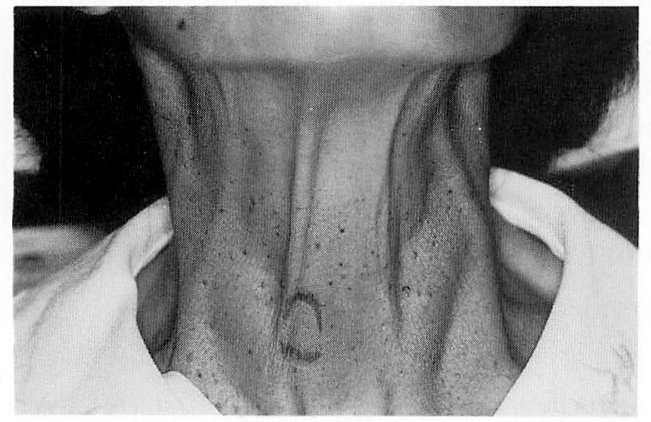

図 1 頸部局所所見

約 $15 \times 17 \mathrm{~mm}$ 大の腫瘤を触知した。

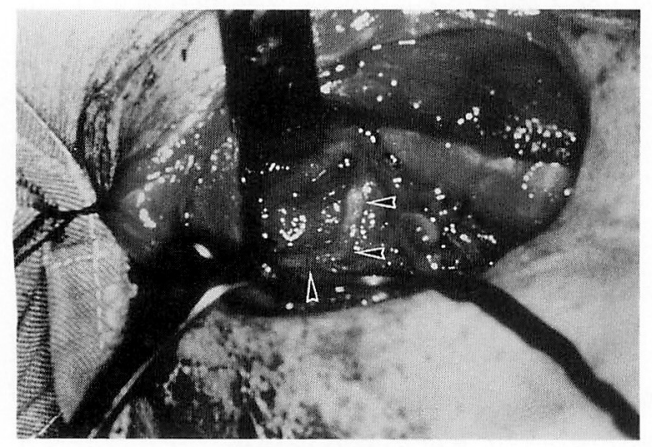

図 2 術中所見

右迷走神経上り非反回神経（矢印）が直接分枝し ていた.
状腺右葉切除術を行った，前頸部に襟状皮膚切 開を加光，型のごとく甲状腺右葉を露出した． まず甲状腺峡部下方の気管前面の処理後, 右中 甲状腺静脈を結紮切断した。.次いで上甲状腺動 静脈を結紮切断後, 右葉下極の処理に移った. 我々は通常, この時点で反回神経の確認を行っ ている．本症例では入念に反回神経の確認を行 ったが，通常の位置に反回神経を垫めなかった． そのため注意深く甲状腺周囲を上極に向かって 剥離を進めて行くと, 図 $2 \cdot 3$ 亿示す上うに直 径約 $2 \mathrm{~mm}$ 大のやや太い神経と思われる索状物 を発見した，その索状物を追跡してみると，一 端は総頸動脈の後面を通り迷走神経につながっ て拈り，他端は輪状軟骨後側面で喉頭に入って いた。矢の索状物を完全に保存し，峡部で甲状

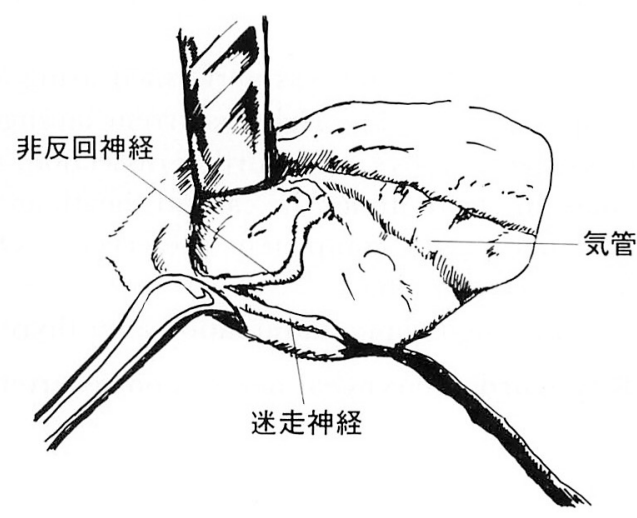

図 3 図 2 のシェーマ

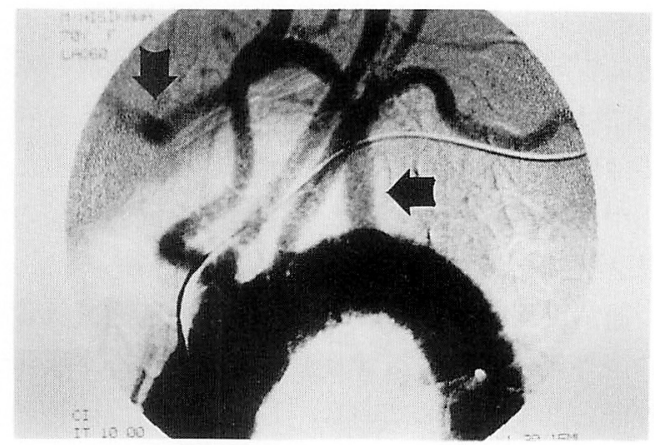

図 4 DSA 所見

右鎖骨下動脈 (矢印) が大動脈弓の最終分枝とな っている。 
腺を切断し，甲状腺右葉切除術を終えた。

甲状腺腫瘍の病理組織学的診断は fetal type の follicular adenoma で，術後は反回神経麻痺 や他の合併症もなく，経過は良好である。

また術後の食道造影では，ほぼ大動脈の高さ で食道後壁に右鎖骨下動脈によると思われる压 痕を認めた。さらに Digital Subtraction Angiograph (DSA) により右鎖骨下動脈が大動 脈の最終枝となっている破格であることが確喼 された（図 4).

\section{考按}

non-recurrent laryngeal nerve の報告は, 1823年に Stedman が行ったものが最初とされ ており，彼は女性の剖検例で右鎖骨下動脈起始 異常を伴った右 non-recurrent laryngeal nerve の一例を報告している112)。また1932年に Pemberton らリがバセドウ病症例の手術時，本 例に遭遇し，臨床上重要な問題として本症を取 り上げ，その後本症に関する報告がしばしばな されている。

本症の成因は, 発生学的な形態異常と考兄ら れておう，特に右鎖骨下動脈起始異常と関連が 深いとされている2)ー7，成書8991によると胎生時 に出現寸る左右 6 対の鰓弓動脈のらち，右第 4 鰓弓動脈が右鎖骨下動脈の原基となる，反回神

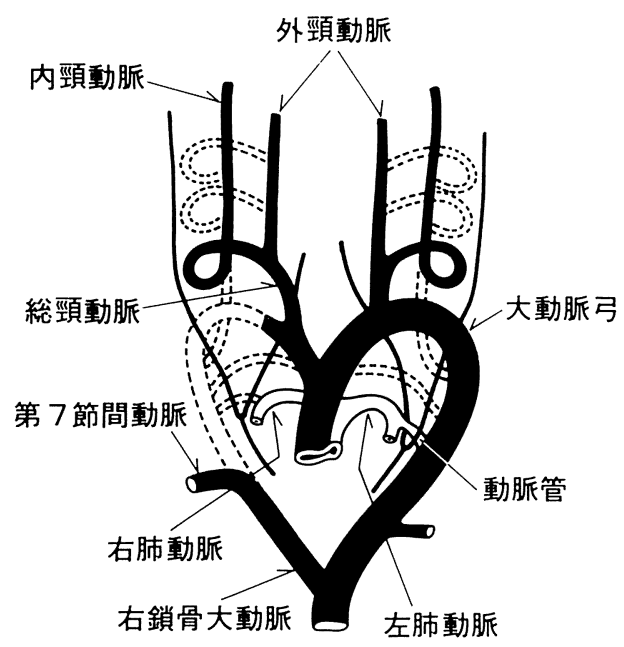

図 5 非反回神経発生のシェーマ
経の主幹である迷走神経は，この第 4 鰓弓動脈 付近から発生するため, 心蔵などの縦隔内臟器 が胸腔内に下降するにしたがって反回神経も下 降し，通常の位置に位置する。しかし石鎖骨下 動脈起始異常では，右第 4 鰓弓動脈と背側動脈 の起始が発生途上で閉塞・消失するため, 左総 頸動脈と左鎖骨下動脈の間で大動脈の短縮を受 け，右鎖骨下動脈の起始が大左鎖骨下動脈起始の 直下から出る。そのため石反回神経は反回すべ きものがないため，迷走神経から直接知頭には いる（図５）。また右鎖骨下動脈が左鎖骨下動 脈起始付近から右上腕に達するためには，食道 の背後で正中を横切るため, 時に器下障害の原 因となる。

通常先に述べたごとく, non-recurrent laryngeal nerve は右側に起こり左側は非常に稀であ る. 左 non-recurrent laryngeal nerve について は，我々が渉猟する限り Henry ら゙による2 例の報告を認めるのみで，そのいずれの症例も 内臓逆位，左鎖骨下動脈の異常を伴らものであ った，以上上り存反回神経を術中確認した症例 に拈ける本症の発生頻度を見てみると Friedman ら4) は270側中 3 例 (0.9\%), Stewart ら2) は1776側中 6 例 $(0.3 \%)$ と報告している。術 側を考慮しない報告では，Katz ${ }^{5)}$ は400)例中6 例 $(1.5 \%)$, Sanders $5^{6)}$ は1000例 7 例 $(0.7$ $\%)$, Wijetilaka ${ }^{\top}$ は203例中 2 例 $(0.9 \%)$, Stewart ら ${ }^{2)}$ は2101例中 6 例 $(0.2 \%)$ と報告し ている.いずれにしても，本症の手術例におけ る発生頻度は $1 \%$ 前後であり, やはり本症は稀 と考光られる。しかし多くの報告者(2)(7)1(0)11)が 述べているように，甲状腺や副甲状腺手術の際 に反回神経の損傷を避けるために，本症の存在 をぜひ知っておかねばならない。さらに右 non-recurrent laryngeal nerve とそれより細い 右反回神経が同時に存在した症例も報告されて 扣り (6), 甲状腺後面の手術操作が必要な場合に は, 慎重な反回神経の確認を必ず行わなければ ならないと考えられる。

1981年～1988年の 8 年間に，教室で初回手術 
を行った甲状腺疾患は241例で，その内訳は甲 状腺腫瘍219例，バセドウ病22例であった。教 室では甲状腺腫瘍の手術時には全例反回神経の 確認を行っているが，バセドウ病では行ってい ない，そのためバセドウ病症例を除外した，教 室での甲状腺手術例に打ける non-recurrent laryngeal nerve の頻度は219例中 1 例 $(0.4 \%)$ であり，従来の報告とほぼ同様であった。

本症例における non-recurrent laryngeal nerve の成因は，DSA 所見より右鎖骨下動脈 起始異常によると考えられる。また本破格では 前述したごとく，臙下障害を訴えることもある が，本症例では特に訴えはなかった。

$$
\text { まとめ }
$$

69歳，女性の甲状腺腫瘍症例（follicular adenoma)に执いて，右 non-recurrent laryngeal nerve を経験したので報告した。術中反回神経 の確認時に戸惑いを覚え，本症の存在を改めて 認識するとともに，この様な症例も存在するこ とから，手術による反回神経の損傷をさけるた め, 術中に批ける反回神経確認の必要性を強調 した。

本論文の要旨は第51回耳鼻咽喉科臨床学会 (平成 元年 7 月）にてロ述した.

\section{参考文献}

1) Pemberton J deJ and Beaver MG : Anomaly of right recurrent laryngeal nerve. Surg Gynecol \& Obstet $54: 594 \sim 595,1932$.

2) Stewart GR, Mountain JC and Colcock BP :
Non-recur-rent laryngeal nerve. Br J Surg 59 : 379 381, 1972.

3) Henry JF, Audiffret J and Plan M : Le nerf la arynge inferieur non recurrent. J Chir $122: 391$ $\sim 397,1985$.

4) Friedman M, Toriumi DM, Grybauskas V, et al : Nonrecurrent laryngeal nerve and their clinical significance. Laryngoscope $96: 87 \sim 90,1986$.

5) Katz AD : Extralaryngeal division of the recurrent laryngeal nerve-report on 400 patients and 721 nerves measured-. Am J Surg 152 : 407 410, 1986.

6) Sanders G, Uyeda RY and Karian MS : Nonrecurrent inferior nerves and their association with a recurrent branch. Am J Surg 146 : 501 503, 1983.

7) Wijetilaka $\mathrm{SH}$ : Non-recurrent laryngeal nerve. Br J Surg $65:$ 179 181, 1978.

8）Langman J 著, 沢野十蔵 訳: 人体発生学 第 3 版. 医歯薬出版, 東京, 1980 .

9) 岡本直正 編: 臨床人体発生学. 南江堂, 東京, 1983.

10) Neminoff PM and Katz AD : Extralaryngeal divisions of the recurrent laryngeal nerve -surgical and clinical significance-. Am J Surg $144:$ 466 469, 1982.

11) Nobles ER : Nonrecurrent laryngeal nerve. Arch Surg $100: 741 \sim 742,1970$.

$$
\left(\begin{array}{l}
\text { 別刷請求先: 田中 治 } \\
\mathbf{T} 634 \text { 橝原市四条町 } 840 \\
\text { 奈良県立医科大学耳鼻咽喉科学教室 }
\end{array}\right)
$$

